\title{
PEDAGOGICAL SYSTEM FOR FORMING PROFESSIONAL ETHICS IN FUTURE SOCIAL WORKERS AT UNIVERSITIES
}

\author{
Roksoliana Zozuliak-Sluchyk, \\ PhD in Pedagogy, Associate Professor Department of Social Pedagogy and Social Work, Vasyl Stefanyk Precarpathian \\ National University \\ http://orcid.org/0000-0001-6066-590X \\ e-mail: zozulyak_roksolyana@ukr.net
}

\begin{abstract}
The article presents key components of a pedagogical system for professional and ethical training of future social workers, which contribute to increasing their level of professional ethics. It determines the essence of the pedagogical system, which unities the processes of forming, developing, education and learning with all forms, methods and terms of their occurrence.

The pedagogical system for forming professional ethics in future social workers at universities is described. It is considered as the multiplicity of interrelated components necessary for an organized and purposeful professional and pedagogical influence on the process of developing moral and ethical qualities in future specialists. The objectives of the pedagogical system for forming professional ethics in future social workers are determined. They are the following: professional and ideological (to form moral consciousness in students; to intensify their activities in professional and ethical training); behavioural and deontological (to facilitate the processes of decision-making in accordance with the requirements of professional ethics, to acquire skills in ethical modelling and predicting production situations, to follow moral and ethical norms); personally significant (to consolidate such personal qualities as humanism, ethical maturity, responsibility, sense of justice, dignity and respect for others, tolerance, politeness, decency, empathy, attentiveness, diligence, sincerity, sociability, social adaptability).

The possible stages of forming professional ethics in future social workers at universities are outlined. They are as follows: the motivation and goals stage (preparing students to understand the goals of professional training, which enhance their motivation to form professional ethics); the procedure stage (it builds relevant knowledge, skills, experience and develops personally and professionally important qualities in students with the help of content, forms, methods and technologies); the evaluation and diagnostics stage (it verifies the efficiency of the introduced pedagogical system and is implemented through such components as motivation and values, cognitive and ideological aspects, activities and behaviour, personal and positional aspects, reflexive and creative aspects).
\end{abstract}

Keywords: pedagogical system, professional ethics, social worker, university, educational process.

Introduction. The processes of updating and reforming higher education, certain socioeconomic changes in society and the growing number of the population who need social assistance and protection have caused the increasing requirements for professional training of future social workers. The efficiency of such training at universities depends on the capacity of students for self-development, selfstudy, self-organization and self-realization. Therefore, one should pay particular attention to the systemic approach in order to solve the problems of developing and reforming modern higher education. It is the factor of transforming the acquired experience into personal and socially significant psychological characteristics of a person.

Materials and methods. Such scholars as B. Bespalko, B. Beziazychnyi, M. Chunosov, I. Druz, A. Kalenskyi, O. Karpenko, V. Kuzmina, 
M. Mykhniuk, H. Skachkova dealt with the problem of developing a system of professional training. For one, B. Beziazychnyi (2016) described the system for forming ethical competency in future teachers of physical education. A. Kalenskyi (2016) justified the pedagogical system of developing professional and pedagogical ethics in future subject teachers in higher education institutions specializing in agriculture and nature protection. M. Mykhniuk (2017) outlined the main components of a methodical system for developing a pedagogical culture in teachers who teach construction-oriented subjects. However, the pedagogical system for forming moral qualities in future social workers at universities has not been properly studied yet.

Research methods include theoretical analysis and study of the system for professional training of specialists at universities.

The research aim is to justify the pedagogical system for professional and ethical training of future social workers at universities, which contributes to increasing their level of professional ethics.

Results and discussions. The conducted analysis of current conditions for forming professional ethics in future social workers at universities allows one to look at the systemic approach to studying the problem from a different angle. It involves the unity of interrelated pedagogical phenomena (elements), which are aimed at achieving a certain pedagogical result.

Some scholars interpret a pedagogical system as a combination of all key components, which unite the processes of forming, developing, education and learning with all forms, methods and terms of their occurrence (Fokshek, 2011, p. 207).

The current research pays particular attention to N. Kuzmina's views on the essence of the pedagogical system (2002, pp. 139-145). First, she introduced the very concept of a pedagogical system and defined its structural components. They are: 1) educational information; 2) pedagogical communication tools (forms, methods, techniques); 3) participants in the education process; 4) teacher; 5) goals of educational activities. In addition, the scholar identified the functional components, which should provide a link between the structural components (constructive, communicational, organizational and prognostic).

The structural components of the pedagogical system are the main characteristics of the educational process, whose range and presence distinguish them from all other systems. They include goals, educational information, pedagogical communication tools, students and teachers (Ortynskyi, 2009, p. 32). Consequently, the pedagogical system sets certain goals and consists of specific components.

Given the current functioning of the educational sector, only the prognostic approach to justifying goals of the pedagogical system at universities will make it possible to most accurately take into account the new trends in the development of society and all its spheres, production and provision of social assistance, as well as scientific, pedagogical, informational and other activities.

Still, the prognosis stage is rather important to the educational process at universities. Without it, one cannot fully take into account the continuous changes taking place today. If organized properly, the planned actions will be implemented at a very advanced pace, which will positively affect the quality of future specialists' training.

The process of forming professional ethics in future social workers requires that a modern pedagogical system for professional and ethical training should be built based on innovations, which are a set of interrelated components, necessary for an organized and purposeful professional and pedagogical influence on the process of developing moral and ethical qualities in future social workers at universities.

The pedagogical system for forming professional ethics in future social workers includes:

$\checkmark$ applying forms and methods of active context and simulation learning, which motivate students to acquire professional ethical knowledge, skills and abilities;

$\checkmark$ modelling professional and ethical activities in the educational process by motivating students to invent and solve moral and ethical tasks and master the course in Ethics of Social Work;

$\checkmark$ involving students into professional and ethical activities, which includes consolidating the acquired knowledge and skills and applying different forms of social work in practice;

$\checkmark \quad$ building the training content based on the development level of modern social, informational, pedagogical technologies and relevant to future professional activities;

$\checkmark$ promoting a proactive character of professional training, which should be based on the process of forming professional ethics and professionally important qualities in future specialists in the context of educational, professional and ethical activities (Chunosov, 2014, p. 117).

As for the objectives of the pedagogical system for forming professional ethics in future social workers, they are preliminarily divided into the following groups:

$\checkmark$ professional and ideological (to form moral consciousness in students; to intensify their activities in professional and ethical training);

$\checkmark$ behavioural and deontological (to facilitate the processes of decision-making in accordance with the requirements of professional ethics, to acquire skills in ethical modelling and predicting production 
situations, to motivate students to be responsible, initiative and demand more of themselves and others, to follow moral and ethical norms);

$\checkmark$ personally significant (to consolidate such personal qualities as humanism, ethical maturity, personal and social responsibility, sense of justice, dignity and respect for others, tolerance, politeness, decency, empathy, ability to understand the client and provide high-quality services, attentiveness, diligence, sincerity, sociability, social adaptability, ability to conduct a systematic ethical analysis of events and situations, real self-esteem, culture of self-study activities) (Beziazychnyi, 2016, p. 129).

When forming professional ethics in future social workers at universities, one should focus on a purposeful and systematic subject-subject interaction between teachers and students during various activities. In this regard, the main aim consists in non-violent development of moral consciousness and moral development and cultivating positive moral qualities in future specialists based on the basic moral values of norms and standards.

The analysis of different approaches to the educational process proves that any system is characterized by content, procedure and results. Therefore, the pedagogical system is implemented based on the possible stages of forming professional ethics in future social workers at universities, namely the motivation and goals stage, the procedure stage, the evaluation and diagnostics stage.

The motivation and goals stage allows students to identify and understand the set goals in order to enhance their motivation to form professional ethics in the educational process. This stage is realized, first of all, through the content of such courses as Introduction to Profession, The History of Ukrainian Culture, The History of Social Work, Volunteering. At this stage, future social workers form a positive emotional and ethical attitude towards mastering professional and ethical principles of the chosen profession and also develop a humane emotional and ethical attitude towards others.

The procedure stage aims to develop the relevant components of forming professional ethics in future social workers (motivation and values, cognitive and ideological aspects, activities and behaviour, personal and positional aspects, reflexive and creative aspects) through the content of relevant courses and the introduction of relevant forms, methods and innovative technologies. The main goal of the stage is to form relevant professional and ethical knowledge, skills and abilities in students and motivate them to develop personal and moral professional qualities, skills in ethical reflection, etc. The procedure stage is realized through the content of such courses as Introduction to Profession, Ethics of Social Work, Volunteering, The History and Theory of Social Work, Professional Skills of Social Worker, Social Conflictology and Partnership.

The evaluation and diagnostics stage makes it possible to verify the effectiveness of the introduced pedagogical system and determine the level of professional ethics in future social workers. It can be realized through practical work (volunteering, providing social services and other professional activities).

The implementation of the pedagogical system is aimed at increasing the level of professional ethics in future social workers. The main components of professional ethics in future social workers are motivation and values (a positive attitude towards professional ethics, capacity for professional and ethical development and self-development), cognitive and ideological aspects (a system of general and professional ethics), activities and behaviour (a system of profession-oriented, deontological skills), personal and positional aspects (professional and ethical views, personally moral and professionally important qualities), reflexive and creative aspects (ethical reflection). The outlined components are the basis for determining the criteria, indicators and levels for forming professional ethics in future social workers at universities.

The functioning of the pedagogical system is subject to the patterns associated with the internal structure of the system itself when the change of one or several of its components will change the entire system.

Conclusions. The described pedagogical system is based on the following: the process of forming professional ethics in future social workers at universities is integral and based on the unity of its content, functional and personal components. They are aimed at forming students' knowledge and skills in professional ethics and establishing an interaction with the participants in the educational process due to deepening ethical and professional orientation, professionally important personal qualities. Further research should verify the effectiveness of the introduced system in professional training of future social workers at universities.

\section{List of references}

Без'язичний, Б. І., 2016. Теоретичні і методичні засади формування етичної компетентності майбутнього вчителя фізичної культури у процесі професійної підготовк. Доктор наук. - Харківський національний педагогічний університет.

Каленський А. А., 2016. Розвиток професійно-педагогічної етики у майбутніх викладачів спеиіальних дисичиплін. Київ: ЦП "Компринт". 
Кузьмина, Н. В., ред.. 2002. Методы системного педагогическогоисследования: учеб. пособие. - М.: Народное образование.

Михнюк М. І., 2017. Теоретичні і методичні основи розвитку професійної культури викладачів спеціальних дисииплін будівельного профілю. Доктор наук. - Інституті професійно-технічної освіти НАПН України.

Ортинський, В. Л., 2009. Педагогіка вищяої иколи: навч. посіб. [для студ. вищ. навч. закл.]. К.: Центр учбової літератури.

Фокшек, А. В., 2011. Системний і синергетичні підходи як модель сучасного педагогічного процесу. Науковий вісник Мелітопольського держ. пед. ун-ту: зб. наук. ст., 6, с. 213-220.

Чуносов, М., 2014. Концептуальні положення педагогічної системи формування професійної готовності майбутніх соціальних педагогів до профілактики делінквентної поведінки неповнолітніх. Науковий вісник Східноєвропейського національного університету імені Лесі Українки Розділ IV: Професійна освіта, 8, с. 115-119.

\section{Translated \& Transliterated}

Beziazychnyi, B.I., 2016. Teoretychni i metodychni zasady formuvannia etychnoi kompetentnosti maibutnoho vchytelia fizychnoi kultury u protsesi profesiinoi pidhotovk [Theoretical and methodical principles of forming ethical competency in future physical education teacher during professional training]. Doktor nauk. - Kharkivskyi natsionalnyi pedahohichnyi universytet, [in Ukrainian].

Kalenskyi A.A., 2016. Rozvytok profesiino-pedahohichnoi etyky u maibutnikh vykladachiv spetsialnykh dystsyplin [Developing professional and pedagogical ethics in future subject teachers]. Kyiv: TsP "Komprynt", [in Ukrainian].

Kuzmina, N.V., red.. 2002. Metody sistemnogo pedagogicheskogo issledovaniya: ucheb. Posobie [Methods of systemic pedagogical research]. M.: Narodnoe obrazovanie [National Education], [in Russian].

Mykhniuk, M.I., 2017. Teoretychni i metodychni osnovy rozvytku profesiinoi kultury vykladachiv spetsialnykh dystsyplin budivelnoho profiliu [Theoretical and methodical principles of developing professional culture in teachers teaching construction-oriented subjects]. Doktor nauk. Instytut profesiino-tekhnichnoi osvity NAPN Ukrainy, [in Ukrainian].

Ortynskyi, V.L., 2009. Pedahohika vyshchoi shkoly [Pedagogy of higher education]: navch. posib. [dlia stud. vyshch. navch. zakl., [in Ukrainian].

Fokshek, A.V., 2011. Systemnyi i synerhetychni pidkhody yak model suchasnoho pedahohichnoho protsesu [Systemic and synergetic approaches as a model of a modern pedagogical process]. Naukovyi visnyk Melitopolskoho derzavnogo. pedagogichnogo. Universytetu [Scientific Journal of Melitopol State Pedagogical University]: zb. nauk. st., 6, s. 213220, [in Ukrainian].

Chunosov, M., 2014. Kontseptualni polozhennia pedahohichnoi systemy formuvannia profesiinoi hotovnosti maibutnikh sotsialnykh pedahohiv do profilaktyky delinkventnoi povedinky nepovnolitnikh [Conceptual principles in the pedagogical system for forming future social educators' professional readiness to prevent delinquent behaviour of adolescents]. Naukovyi visnyk Skhidnoievropeiskoho natsionalnoho universytetu imeni Lesi Ukrainky. Rozdil IV : Profesiina osvita [Scientific Journal of Lesia Ukrainka Eastern European National University. Unit IV: Professional Education], 8, s. 115-119, [in Ukrainian].

\section{Педагогічна система формування професійної етики майбутніх соціальних працівників в університетах}

\section{Роксоляна Зозуляк-Случик,}

кандидат педагогічних наук, доцент кафедри соціальної педагогіки та соціальної роботи, Прикарпатський національний університет імені Василя Стефаника

Реферат. У статті подано ключові компоненти педагогічної системи професійно-етичної підготовки майбутніх соціальних працівників, що сприяють підвищенню рівня сформованості професійної етики в майбутніх фахівців. Визначено суть педагогічної системи як єдності процесів формування, розвитку, виховання і навчання з усіма формами, методами й умовами їх протікання.

Охарактеризовано педагогічну систему формування професійної етики майбутніх соціальних працівників в університетах, яку розглядаємо як множинність взаємопов'язаних компонентів, потрібних для впорядкованого і цілеспрямованого професійно-педагогічного впливу на розвиток морально-етичних якостей особистості майбутніх фахівців. Виокремлено завдання педагогічної системи формування професійної етики майбутніх соціальних працівників, до яких відносять: професійно-світоглядні (сприяють формуванню моральної свідомості студентів, активізації їхньої діяльності у професійно-етичній підготовці); поведінково-деонтологічні (направлені на оволодіння процедурою прийняття рішень відповідно до вимог професійної етики, навичками етичного моделювання і прогнозування виробничих ситуацій, дотримання морально-етичних норм); особистісно-значущі (відповідають за поглиблення таких особистісних якостей, як: гуманізм, етична зрілість, відповідальність, почуття справедливості, гідності та поваги до 
іншої людини, терпимість, ввічливість, порядність, емпатійність, уважність, старанність, щирість, комунікабельність, соціальна адаптованість).

Окреслено умовні етапи формування професійної етики майбутніх соціальних працівників в університетах: мотиваційно-цільовий (зумовлює усвідомлення цілей професійної підготовки студентами, що активізують їхню мотивацію до формування професійної етики); процесуальний (за допомогою змісту, форм, методів і технологій сприяє формуванню відповідних знань, умінь, навичок, особистісно і професійно важливих рис); оцінно-діагностичний (перевіряє ефективність упровадження педагогічної системи й реалізується у компонентах - мотиваційно-ціннісному, когнітивно-світоглядному, діяльнісно-поведінковому, особистісно-позиційному, рефлексивно-творчому).

Ключові слова: педагогічна система, професійна етика, соціальний працівник, університет, освітній процес.

Received: 08 April 2019

Accepted: 19 May 2019 